\title{
Daya Antibakteri Filtrat Asam Laktat dan Bakteriosin Lactobacillus bulgaricus KS1 dalam Menghambat Pertumbuhan Klebsiella pneumoniae Strain ATCC 700603, CT1538, dan S941
}

\author{
Prima Nanda Fauziah, ${ }^{1}$ Jetty Nurhajati, ${ }^{2}$ Chrysanti $^{3}$ \\ ${ }^{1}$ Prodi Analis Kesehatan, Sekolah Tinggi Ilmu Kesehatan Jenderal Achmad Yani, ${ }^{2}$ Jurusan Biologi, Fakultas \\ Matematika dan Ilmu Pengetahuan Alam, Universitas Padjadjaran, ${ }^{3}$ Bagian Mikrobiologi, Fakultas Kedokteran, \\ Universitas Padjadjaran
}

\begin{abstract}
Abstrak
Lactobacillus bulgaricus menghasilkan asam laktat dan bakteriosin yang memiliki efek farmakologik, di antaranya sebagai antibakteri. Klebsiella pneumoniae penyebab pneumonia masih merupakan masalah kesehatan masyarakat di negara tropis. Penelitian ini bertujuan untuk mengetahui daya antibakteri asam laktat dan bakteriosin $L$. bulgaricus terhadap berbagai strain K. pneumoniae secara in vitro dengan menggunakan teknik agar tuang dan difusi cakram, selanjutnya data dianalisis dengan ANAVA yang dilanjutkan dengan uji Duncan's multiple range test (DMRT). Penelitian dilakukan di Laboratorium Mikrobiologi Rumah Sakit Pendidikan Universitas Padjadjaran, Bandung pada bulan Agustus-Oktober 2012. Hasil menunjukkan bahwa konsentrasi 30\% filtrat asam laktat dan $20 \%$ filtrat bakteriosin L. bulgaricus bersifat bakterisidal terhadap berbagai strain K. pneumoniae. Semakin besar konsentrasi filtrat asam laktat dan bakteriosin L. bulgaricus menunjukkan pengaruh peningkatan daerah hambat berbagai strain K. pneumoniae. Analisis data dengan ANAVA yang dilanjutkan dengan uji Duncan's multiple range test (DMRT) menunjukkan bahwa pengaruh konsentrasi filtrat terbesar terhadap daerah hambat K. pneumoniae diperoleh pada perlakuan konsentrasi $90 \%$ filtrat asam laktat L. bulgaricus, sedangkan daerah hambat terbesar diperoleh K. pneumoniae strain ATCC 700603 pada konsentrasi 90\% filtrat bakteriosin sebesar 16,667 mm. Simpulan, filtrat asam laktat dan bakteriosin L. bulgaricus memiliki daya antibakteri terhadap pertumbuhan $K$. pneumoniae. Besar daya antibakteri L. bulgaricus terhadap pertumbuhan K. pneumoniae dipengaruhi oleh jenis filtrat, konsentrasi filtrat L. bulgaricus, dan strain bakteri K. pneumoniae. [MKB. 2015;47(1):35-41]
\end{abstract}

Kata kunci: Antibakteri, asam laktat, bakteriosin, Klebsiella pneumoniae, Lactobacillus bulgaricus

\section{Antibacterial Effect of Lactic Acid Filtrate and Bacteriocins of Lactobacillus bulgaricus KS1 on Inhibiting the Growth of Klebsiella pneumoniae ATCC 700603, CT1538, and S941 Strains}

\begin{abstract}
Lactobacillus bulgaricus produces lactic acid and bacteriocin which have been reported to have various pharmacologic properties, including their role an antibacterial agent. Klebsiella pneumoniae, as an agent of pneumonia, remains a public health problem in tropical countries. This study was aimed to observe the antibacterial activities of lactic acid filtrate and bacteriocins of L. bulgaricus toward againsts $K$. pneumoniae strains by in vitro experiment. The experiment took place in Microbiology Laboratory, Teaching Hospital, Padjadjaran University, Bandung, August-October 2012. In vitro laboratory analytic study has been conducted on lactic acid filtrate and bacteriocins of $L$. bulgaricus against the $K$. pneumoniae strains. The study used agar pour plate and agar disk diffusion method and analyzed by ANAVA followed by Duncan's multiple range test (DMRT). The 30\% lactic acid filtrate and $20 \%$ bacteriocins filtrate concentrations of L. bulgaricus showed bactericidal characteristics againts the growth of K. pneumoniae strains. Greater concentration of lactic acid filtrate and bacteriocins of L. bulgaricus led toincreasing effect of growth inhibition zones of $K$. pneumoniae strains. Statistical analysis of variance (ANOVA) showed that the greatest concentration effect of L. bulgaricus filtratefor inhibiting K. pneumoniae strains was achieved in $90 \%$ lactic acid filtrate concentration treatment, whereas the greatest inhibition zones for $K$. pneumoniae ATCC 700603 was obtaubed in $90 \%$ bacteriocins filtrate concentration, amounting $16.667 \mathrm{~mm}$. In conclusion, lactic acid filtrate and bacteriocins L. bulgaricus have antibacterial effects on K. pneumoniae. The level of antibacterial effect of L. bulgaricus against the growth of K. pneumoniae strains depends on the type of filtrate, L. bulgaricus filtrate concentration, and K. pneumoniae strain. [MKB. 2015;47(1):35-41]
\end{abstract}

Key words: Antibacterial, bacteriocins, Klebsiella pneumoniae, lactic acid, Lactobacillus bulgaricus

Korespondensi: Prima Nanda Fauziah, S. Si, Prodi DIII Analis Kesehatan STIKES Jenderal Ahmad Yani, Jalan Terusan Jenderal Sudirman, Cimahi, mobile 08572136 8609, e-mail: primanandafauziah@analis-ayani.ac.id 


\section{Pendahuluan}

Probiotik ialah suatu mikroorganisme hidup yang apabila diberikan dalam jumlah adekuat akan bermanfaat bagi kesehatan penjamu. ${ }^{1}$ Agen antibakteri seperti asam laktat dan bakteriosin yang dimiliki oleh bakteri probiotik mempunyai efek yang sangat penting dalam menghambat pertumbuhan bakteri-bakteri patogen. ${ }^{2}$ Hal ini dikarenakan asam laktat mampu menurunkan pH menjadi rendah sehingga bakteri patogen akan sulit bertahan hidup, sedangkan bakteriosin menghambat produksi energi dan biosintesis protein pada bakteri patogen. ${ }^{3}$

Salah satu bakteri probiotik yang paling umum dipergunakan adalah bakteri Lactobacillus bulgaricus yang merupakan salah satu bakteri probiotik dari genus Lactobacillus yang telah lolos uji klinis dan juga mampu menyekresikan enzim yang dapat mengatasi intoleran terhadap laktosa, menormalkan komposisi bakteri saluran pencernaan yang terbunuh karena konsumsi antibiotik, serta menghasilkan agen antibakteri seperti asam laktat dan bakteriosin yang mampu menghambat pertumbuhan bakteri patogen. ${ }^{4}$

Kartasasmita ${ }^{5}$ menyatakan bahwa pneumonia merupakan penyakit penyebab kematian kedua paling tinggi setelah diare pada balita. Bakteri merupakan penyebab pneumonia paling sering (90\%). Bakteri paling sering yang menyebabkan pneumonia, yaitu Streptococcus pneumoniae, Staphylococcus sp., dan Klebsiella pneumoniae. ${ }^{6}$

Klebsiella pneumoniae merupakan bakteri yang terpenting karena penyebab pneumonia paling besar pada bayi dan juga orang dewasa yang diperoleh dari infeksi rumah sakit. Hal ini terbukti bahwa sekitar 93\% bayi dan orang dewasa terkena pneumonia akibat infeksi $K$. pneumoniae. Dalam keadaan sehat tidak terjadi pertumbuhan kolonisasi $K$. pneumoniae yang disebabkan oleh mekanisme pertahanan tubuh. Apabila terjadi ketidakseimbangan daya tahan tubuh, bakteri patogen ini mampu berkembang biak lebih cepat dan menyebabkan penyakit pneumonia. ${ }^{7}$

Pemakaian antibiotikyang sebelumnya efektif mengobati penyakit pneumonia saat ini justru menimbulkan efek samping berupa terbunuhnya bakteri baik dalam usus yang berperan dalam menyeimbangkan dan juga meningkatkan daya tahan tubuh. Selain itu, antibiotik diketahui dapat menimbulkan resistensi terhadap bakteri penyebab penyakit infeksi. ${ }^{8,9}$ Oleh sebab itu, dibutuhkan salah satu alternatif yaitu dengan pemberian probiotik. ${ }^{10}$

Penelitian mengenai daya antibakteri dan manfaat terapeutik probiotik terhadap berbagai strain K. pneumoniae sebagai bakteri uji serta penelitian mengenai daya antibakteri filtrat asam laktat dan bakteriosin L. bulgaricus terhadap pertumbuhan berbagai strain $K$. pneumoniae belum banyak terungkap. Oleh sebab itu, tujuan penelitian ini untuk menguji daya antibakteri filtrat asam laktat dan bakteriosin L. bulgaricus dalam hal menghambat pertumbuhan berbagai strain bakteri $K$. pneumoniae perlu dilakukan untuk mengurangi pertumbuhan bakteri yang resisten terhadap antibiotik. Penggunaan filtrat probiotik juga merupakan upaya memperoleh langkah yang paling baik mendapatkan metode pencegahan dan pengobatan yang aman untuk mengatasi penyakit pneumonia yang disebabkan oleh K. pneumoniae.

\section{Metode}

Penelitian ini dilaksanakan di Laboratorium Mikrobiologi Rumah Sakit Pendidikan Fakultas Kedokteran Universitas Padjadjaran pada bulan Agustus-Oktober 2012. Penelitian ini terdiri atas dua tahap penelitian. Tahap pertama menguji MIC filtrat asam laktat dan bakteriosin L. bulgaricus terhadap pertumbuhan berbagai strain bakteri K. pneumoniae menggunakan metode agar tuang (pour plate). Tahap kedua menguji efektivitas filtrat asam laktat dan bakteriosin L. bulgaricus terhadap besar daerah hambat pertumbuhan berbagai strain K. pneumoniae mempergunakan metode difusi agar (kertas cakram).

Kultur bakteriyang digunakan pada penelitian ini adalah L. bulgaricus KS1 yang diperoleh dari hasil isolasi Yoghurt King Plain dan K. pneumoniae strain ATCC 700603, CT1538 (cairan tubuh pasien ke 1538), dan S941 (sputum pasien ke 941) yang diperoleh dari koleksi Laboratorium Mikrobiologi Fakultas Kedokteran Universitas Padjadjaran. Strain CT1538 dan S941 diperoleh pada saat mengisolasi K. pneumoniae dari pasien, sedangkan strain ATCC 700603 merupakan K. pneumoniae standar yang belum menunjukkan resistensi terhadap obat-obatan antipneumonia. L. bulgaricus ditumbuhkan pada media the Man Rogosa Sharpe (MRS) agar (OXOID CM0361) yang telah ditambahkan dengan $5 \% \mathrm{CaCO}_{3}$ dan bakteri $K$. pneumoniae ditumbuhkan pada Mac Conkey agar (MCA) (OXOID CM0007).

Filtrat asam laktat $L$. bulgaricus KS1 diperoleh dengan cara menyentrifugasi $L$. bulgaricus KS1 yang telah teraktivasi dalam MRS broth (OXOID CM0359) dengan kecepatan 6.000 rpm pada suhu $4^{\circ} \mathrm{C}$ selama 15 menit untuk memisahkan 
sel dengan filtratnya (supernatan). Filtrat yang diperoleh disterilkan memakai filter milipore $0,22 \mu \mathrm{m}$, kemudian filtrat di dalam tabung dipapar di bawah sinar UV dengan jarak $40 \mathrm{~cm}$ selama 40 menit. ${ }^{11}$ Selain itu, filtrat bakteriosin probiotik L. bulgaricus KS1 diperoleh dengan menyentrifugasi bakteri yang telah teraktivasi dalam MRS broth (OXOID CM0359) dengan kecepatan $6.000 \mathrm{rpm}$ pada suhu $4^{\circ} \mathrm{C}$ selama 15 menit untuk dapat memisahkan sel dengan filtratnya, selanjutnya pH dijadikan 7,0 dengan penambahan $\mathrm{NaOH} 2 \mathrm{~N}$ dan disterilkan dengan filter millipore $0,22 \mu \mathrm{m} .{ }^{12}$

Pada pengujian MIC dilaksanakan beberapa prosedur, yaitu isolat $K$. pneumoniae yang telah disubkultur pada medium MCA, ditumbuhkan lebih banyak pada brain heart infusion (BHI) broth (OXOID CM1135). Satu ose isolat bakteri $K$. pneumoniae disuspensikan ke dalam tabung sentrifugasi yang berisi $\mathrm{NaCl}$ fisiologis $0,9 \%$ dan disentrifugasi sebanyak dua kali. Supernatan dibuang dan dipindahkan ke dalam tabung yang berisi $\mathrm{NaCl}$ fisiologis 0,9\% serta dihomogenkan. Tahap selanjutnya kekeruhan disetarakan dengan

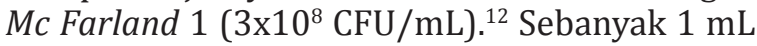
suspensi bakteri ditambahkan ke dalam filtrat asam laktat atau bakteriosin L. bulgaricus pada MRS broth untuk setiap konsentrasi, yaitu $\mathrm{NaCl}$ (kontrol 1), 10\%, 20\%, 30\%, 40\%, 50\%, 60\%, $70 \%, 80 \%, 90 \%$, dan 100\%. Suspensi diinkubasi selama 24 jam pada temperatur $37^{\circ} \mathrm{C}$, kemudian hasil inkubasi diambil 1 ose dan digoreskan pada medium MCA dan diinkubasi selama 24 jam pada temperatur $37^{\circ} \mathrm{C}$. Pengamatan dilakukan dengan mengamati pertumbuhan bakteri K. pneumoniae pada medium MCA di dalam cawan petri. ${ }^{13,14}$

Setelah pengujian MIC dilakukan uji efektivitas filtrat L. bulgaricus menggunakan metode difusi agar (kertas cakram). Koloni bakteri uji $K$. pneumoniae yang telah disubkultur pada MCA diambil sebanyak 1 ose bulat dan dimasukkan ke dalam $9 \mathrm{~mL}$ BHI broth dan diinkubasi selama 24 jam pada temperatur $37^{\circ} \mathrm{C} .{ }^{13}$ Satu $\mathrm{mL}$ suspensi bakteri pada BHI broth disuspensikan sebanyak dua kali ke dalam $10 \mathrm{~mL}$ larutan gula tebu dan diinkubasi selama 24 jam pada temperatur $37^{\circ} \mathrm{C}$. Suspensi bakteri dituangkan ke dalam cawan petri yang berisi agar Mueller Hinton (OXOID CM0337) sesudah itu dihomogenkan. Sisa cairan suspensi yang berlebih dibuang ke dalam cairan desinfektan, kemudian kertas cakram yang telah direndam di dalam berbagai konsentrasi filtrat asam laktat atau bakteriosin hasil pengujian MIC (70\%, 80\%, 90\%) diinkubasi selama 24 jam pada temperatur $37^{\circ} \mathrm{C}$. Pengamatan dilakukan dengan mengukur besar daerah hambat pertumbuhan yang terbentuk di sekitar kertas cakram sesudah masa inkubasi. Pengukuran diameter zona hambat ini dilakukan sesuai dengan standar pengukuran daerah hambat yang ditetapkan National Committee for Clinical Laboratory Standard (NCCLS).

Data hasil MIC dianalisis secara deskriptif. Data hasil efektivitas filtrat dianalisis secara statistika dengan sidik ragam dan dilanjutkan Duncan's multiple range test (DMRT) jika berbeda nyata nilai $\mathrm{p}<0,01$ untuk mengetahui perlakuan yang memberikan hasil daya antibakteri terbaik.

\section{Hasil}

Hasil penelitian MIC dengan teknik agar tuang (pour plate) Mueller Hinton memperlihatkan bahwa filtrat asam laktat $L$. bulgaricus KS1 pada konsentrasi 30\% menghambat pertumbuhan $K$. pneumoniae strain ATCC 700603, CT1538, dan S941 (Tabel 1). Keadaan ini terlihat dengan tidak terdapat pertumbuhan bakteri $K$. pneumoniae strain ATCC 700603, CT1538, dan S941 pada medium MCA setelah diinkubasi selama 24 jam.

Tabel 1 Pengaruh Konsentrasi Filtrat Asam Laktat L. bulgaricus terhadap Pertumbuhan Strain K. pneumoniae

\begin{tabular}{|c|c|c|c|c|c|c|c|c|c|c|c|c|c|}
\hline \multirow{2}{*}{ Bakteri Patogen } & \multirow{2}{*}{ Strain } & \multirow{2}{*}{ Ulangan } & \multicolumn{11}{|c|}{ Konsentrasi Filtrat Asam Laktat L. bulgaricus (\%) } \\
\hline & & & $\mathbf{c}_{\mathbf{o}}$ & $\mathbf{c}_{10}$ & $\mathbf{c}_{20}$ & $\mathbf{c}_{30}$ & $\mathbf{c}_{40}$ & $\mathbf{c}_{50}$ & $\mathbf{c}_{60}$ & $\mathbf{c}_{70}$ & $\mathbf{C}_{80}$ & $\mathbf{C}_{90}$ & $\mathbf{c}_{100}$ \\
\hline \multirow{6}{*}{ K. pneumoniae } & \multirow{2}{*}{ ATCC } & $1 x$ & + & + & + & - & - & - & - & - & - & - & - \\
\hline & & $2 x$ & + & + & + & - & - & - & - & - & - & - & - \\
\hline & \multirow{2}{*}{ CT 1538} & $1 x$ & + & + & + & - & - & - & - & - & - & - & - \\
\hline & & $2 \mathrm{x}$ & + & + & + & - & - & - & - & - & - & - & - \\
\hline & \multirow{2}{*}{ S 941} & $1 x$ & + & + & + & - & - & - & - & - & - & - & - \\
\hline & & $2 x$ & + & + & + & - & - & - & - & - & - & - & - \\
\hline
\end{tabular}

Keterangan: +: Pertumbuhan K. pneumoniae; - : Tidak ada pertumbuhan K. pneumoniae; c: Konsentrasi 
Prima N.: Daya Antibakteri Filtrat Asam Laktat dan Bakteriosin Lactobacillus bulgaricus KS1

Tabel 2 Hasil Analisis DMRT Pengaruh Konsentrasi Filtrat Asam Laktat L. bulgaricus terhadap Besar Daerah Hambat Pertumbuhan K. pneumoniae

\begin{tabular}{|c|c|c|c|c|}
\hline \multirow{2}{*}{$\begin{array}{c}\text { Perlakuan } \\
\text { (\%) }\end{array}$} & \multicolumn{3}{|c|}{ Konsentrasi Filtrat Asam Laktat L. bulgaricus } & \multirow{2}{*}{ Notasi } \\
\hline & Rata-rata & Selisih antar & Rata-rata & \\
\hline 70 & 12,556 & & & A \\
\hline 80 & 13,889 & 1,333 & & $\mathrm{Ab}$ \\
\hline 90 & 14,889 & 2,333 & 1,000 & $\mathrm{~B}$ \\
\hline
\end{tabular}

Keterangan: Nilai rata-rata yang diikuti oleh huruf yang tidak sama berbeda nyata menurut Uji DMRT taraf 1\%

Hasil penelitian dengan teknik difusi agar (kertas cakram) memperlihatkan filtrat asam laktat L. bulgaricus KS1 pada konsentrasi $90 \%$ memberikan diameter rata-rata daerah hambat terbesar 15,333 mm untuk K. pneumoniae strain ATCC 700603 (Gambar 1). Pada konsentrasi $70 \%$ dan $80 \%$ diameter rata-rata daerah hambat terbesar di sekeliling kertas cakram adalah 13 $\mathrm{mm}$ untuk $K$. pneumoniae strain CT1538 dan $14,333 \mathrm{~mm}$ untuk $K$. pneumoniae strain ATCC 700603.

Hasil uji analisis varians untuk konsentrasi menunjukkan bahwa nilai $\mathrm{p}=0,000$ lebih kecil dari 0,05 sehingga dapat disimpulkan bahwa ketiga konsentrasi yaitu 70\%, 80\%, dan 90\% menunjukkan perbedaan yang sangat nyata. Hasil uji varians ini kemudian dilanjutkan dengan DMRT yang memperlihatkan konsentrasi 90\% filtrat asam laktat L. bulgaricus KS1 berbeda sangat nyata dibandingkan dengan konsentrasi 70\% dan 90\% (Tabel 2).

Hasil penelitian MIC dengan teknik agar tuang (pour plate) Mueller Hinton menunjukkan filtrat bakteriosin L. bulgaricus KS1 pada konsentrasi 20\% dapat menghambat pertumbuhan bakteri K. pneumoniae strain ATCC 700603, CT1538, dan S941 (Tabel 3). Hal ini terlihat dengan tidak terjadi pertumbuhan K. pneumoniae strain ATCC 700603, CT1538, dan S941 pada medium MCA setelah diinkubasi selama 24 jam.
Hasil penelitian dengan teknik difusi agar (kertas cakram) memperlihatkan filtrat asam laktat L. bulgaricus KS1 pada konsentrasi $90 \%$ memberikan diameter rata-rata daerah hambat terbesar $16,667 \mathrm{~mm}$ pada K. pneumoniae strain ATCC 700603 (Gambar 2). Pada konsentrasi $70 \%$ dan $80 \%$ diameter rata-rata daerah hambat terbesar di sekeliling kertas cakram adalah 15 $\mathrm{mm}$ dan $16 \mathrm{~mm}$ pada K. pneumoniae strain ATCC 700603.

\section{Pembahasan}

Filtrat asam laktat dari L. bulgaricus bersifat mematikan atau bakterisidal pada konsentrasi 30-100\% dan menghambat atau bakteriostatik pada konsentrasi $10-20 \%$ terhadap bakteri $K$. pneumoniae strain ATCC 700603, CT1538, dan S941. Keadaan tersebut menunjukkan bahwa sensitivitas K. pneumoniae strain ATCC 700603, CT1538, dan S941 sama terhadap filtrat asam laktat L. bulgaricus (Tabel 1).

Semua konsentrasi filtrat asam laktat itu mempunyai besar daerah hambat pertumbuhan yang berbeda pada setiap strain bakteri $K$. pneumoniae. Daerah hambat terbesar dihasilkan oleh K. pneumoniae strain ATCC 700603, yaitu $15,333 \mathrm{~mm}$ pada konsentrasi filtrat asam laktat sebesar 90\%, disusul oleh strain S941 sebesar

Tabel 3 Pengaruh Konsentrasi Filtrat Bakteriosin L. bulgaricus terhadap Pertumbuhan Strain K. pneumoniae

\begin{tabular}{|c|c|c|c|c|c|c|c|c|c|c|c|c|}
\hline \multirow{2}{*}{ Bakteri Patogen } & \multirow{2}{*}{ Strain } & \multirow{2}{*}{ Ulangan } & \multicolumn{10}{|c|}{ Konsentrasi Filtrat Bakteriosin L. bulgaricus (\%) } \\
\hline & & & $\mathbf{c}_{10}$ & $\mathbf{c}_{20}$ & $\mathbf{c}_{30}$ & $\mathbf{C}_{40}$ & $\mathbf{C}_{50}$ & $\mathbf{c}_{60}$ & $\mathbf{c}_{70}$ & $\mathbf{c}_{80}$ & $\mathbf{c}_{90}$ & $\mathbf{c}_{100}$ \\
\hline \multirow{6}{*}{ K. pneumoniae } & \multirow{2}{*}{ ATCC } & $1 x$ & + & - & - & - & - & - & - & - & - & - \\
\hline & & $2 x$ & + & - & - & - & - & - & - & - & - & - \\
\hline & \multirow{2}{*}{ CT 1538} & $1 x$ & + & - & - & - & - & - & - & - & - & - \\
\hline & & $2 x$ & + & - & - & - & - & - & - & - & - & - \\
\hline & \multirow{2}{*}{ S 941} & $1 x$ & + & - & - & - & - & - & - & - & - & - \\
\hline & & $2 x$ & + & - & - & - & - & - & - & - & - & - \\
\hline
\end{tabular}

Keterangan: +: Pertumbuhan K. pneumoniae; - : Tidak ada pertumbuhan K. pneumoniae; c: Konsentrasi 


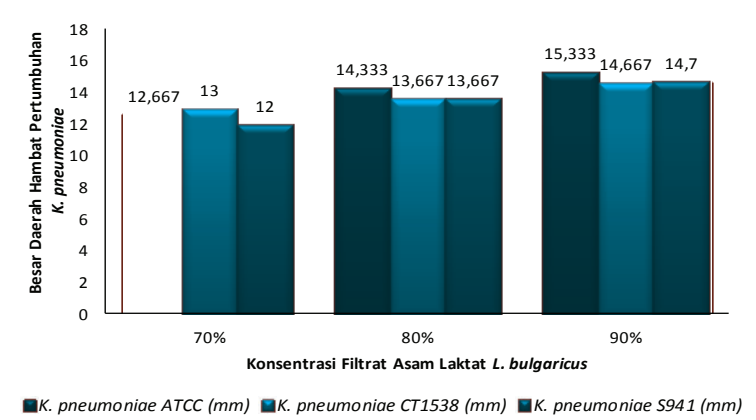

Gambar 1 Efektivitas Filtrat Asam Laktat L. bulgaricus terhadap Besar Daerah Hambat Pertumbuhan Berbagai Strain $K$. pneumoniae

14,7 mm dan strain CT1538 sebesar 14,667 mm pada konsentrasi filtrat asam laktat yang sama (Gambar 1).

Perlakuan berbagai konsentrasi filtrat asam laktat L. bulgaricus (70\%,80\%,90\%) memberikan pengaruh terhadap peningkatan besar daerah hambat dan menunjukkan perbedaan yang nyata dengan daerah hambat terbesar yaitu 14,889 mm pada konsentrasi filtrat asam laktat sebesar $90 \%$ (Tabel 2). Hasil tersebut menunjukkan bahwa semakin besar konsentrasi filtrat asam laktat $L$. bulgaricus, maka semakin besar pula diameter daerah hambat pertumbuhan $K$. pneumoniae yang terbentuk.

Probiotik merupakan bakteri asam laktat $L$. bulgaricus umumnya dapat memecah glukosa menghasilkan asam laktat. Hal ini menyebabkan pH media menjadi rendah $(<4,5)$ sehingga dapat menghambat pertumbuhan bakteri patogen. ${ }^{15}$

Asam laktat yang dihasilkan bakteri probiotik akan berdifusi ke dalam sel mikrob patogen, lalu sel bakteri patogen tersebut akan terdisosiasi sehingga akan mengganggu sistem transportasi nutrisi. Peristiwa disosiasi sel bakteri patogen itu mengakibatkan sel membentuk proton dan anion sehingga keberadaan proton itu mengganggu keseimbangan pengangkutan nutrisi sel bakteri patogen. Oleh sebab itu, bakteri akan berusaha mengeluarkan proton tersebut dari dalam sel. Proses pengeluaran proton ini membutuhkan energi yang tinggi dan mengakibatkan bakteri patogen mati karena kehabisan energi. ${ }^{16}$ Selain itu, asam laktat yang dihasilkan dalam proses fermentasi mampu menurunkan $\mathrm{pH}$ dan keadaan ini akan mengganggu aktivitas enzim sehingga sel bakteri patogen tidak mampu melakukan aktivitas metabolisme. ${ }^{17}$

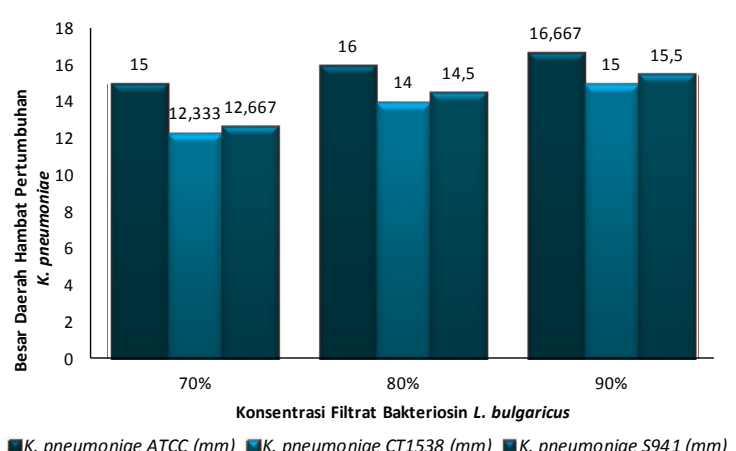

Gambar 2 Efektivitas Filtrat Bakteriosin L. bulgaricus terhadap Besar Daerah Hambat Pertumbuhan Berbagai Strain $K$. pneumoniae

Menurut Ligocka dan Paluszak, ${ }^{18}$ susunan biokimia asam laktat yang dihasilkan bakteri asam laktat (BAL) memiliki kemampuan yang berbeda untuk memberikan efek antagonis pada bakteri patogen. Perlakuan mempergunakan $K$. pneumoniae strain ATCC 700603 menunjukkan perbedaan yang nyata, yaitu dengan membentuk daerah hambat pertumbuhan yang paling besar dibanding dengan $K$. pneumoniae strain CT1538 dan S941. Keadaan ini terjadi karena aktivitas senyawa antimikrob filtrat asam laktat bakteri L. bulgaricus memiliki pengaruh yang berbeda terhadap bakteri patogen dan dapat bersifat bakteriostatik 'bakterisidal' bergantung karakteristik, jenis, dan strain bakteri patogen.

Filtrat bakteriosin dari L. bulgaricus bersifat mematikan atau bakterisidal pada konsentrasi 20-100\% dan menghambat atau bakteriostatik pada konsentrasi $10 \%$ terhadap K. pneumoniae strain ATCC 700603, CT1538, dan S941. Hal tersebutmenunjukkan sensitivitas K. pneumoniae strain ATCC 700603, CT1538, dan S941 sama terhadap filtrat bakteriosin L. bulgaricus (Tabel 3).

Semua konsentrasi filtrat bakteriosin mampu memperlihatkan daerah hambat dengan besar diameter yang berbeda pada setiap strain $K$. pneumoniae. Daerah hambat terbesar dihasilkan oleh K. pneumoniae strain ATCC 700603 yaitu 16,667 mm pada konsentrasi 90\%, disusul oleh strain S941 sebesar 15,5 mm, dan terakhir strain CT1538 sebesar $15 \mathrm{~mm}$ pada konsentrasi yang sama (Gambar 2).

Bakteriosin merupakan senyawa protein yang dieksresikan oleh bakteri probiotik yang bersifat antimikrob dan mampu menekan pertumbuhan bakteri patogen. Perbedaan besar daerah hambat 
pertumbuhan yang dibentuk pada setiap bakteri disebabkan perbedaan aktivitas hambat yang dipengaruhi oleh jenis dinding sel bakteri yang dihambat. Hal ini berpengaruh pada ketahanan suatu bakteri terhadap zat antimikrob karena perbedaan pada struktur dinding sel. Aktivitas produksi bakteriosin oleh bakteri probiotik akan dipengaruhi faktor $\mathrm{pH}$, suhu, sumber karbon, serta fase pertumbuhan. Jenis sumber karbon dan nitrogen yang dipergunakan dalam medium produksi memengaruhi laju pertumbuhan sel bakteri probiotik, yang selanjutnya berpengaruh pada metabolisme produksi bakteriosin. Selain itu, tingkat salinitas medium produksi seperti kandungan garam media juga akan memengaruhi metabolisme produksi bakteriosin itu. Aplikasi bakteriosin sebagai biopreservatif pada bahan pangan tidak mengubah rasa dan tekstur tetapi menghambat pertumbuhan mikrob patogen. ${ }^{19}$

Target utama bakteriosin yaitu membran sitoplasma sel mikrob patogen karena reaksi awal bakteriosin dapat merusak permeabilitas membran dan juga menghilangkan proton motive force (PMF) sehingga menghambat produksi energi dan juga biosintesis protein. Mekanisme aktivitas bakterisidal bakteriosin yaitu berupa bakteriosin kontak langsung dengan membran sel. Proses ini mampu mengganggu potensial membran yaitu berupa destabilitas membran sitoplasma sehingga sel menjadi tidak kuat. Ketidakstabilan membran mampu memberikan dampak pembentukan lubang atau pori pada membran sel bakteri patogen melalui proses gangguan pada PMF. Kebocoran yang terjadi karena pembentukan lubang pada membran sitoplasma tersebut ditunjukkan oleh aktivitas keluar masuknya molekul seluler. Kebocoran ini berdampak penurunan $\mathrm{pH}$ seluler. Pengaruh pembentukan lubang sitoplasma merupakan dampak bakteriosin yang mampu mengubah gradien potensial membran dan juga pelepasan molekul interseluler, serta masuknya substansi ekstraseluler. Peristiwa tersebut berpengaruh menghambat pertumbuhan sel bakteri patogen dan mampu menyebabkan kematian sel bakteri yang sensitif terhadap bakteriosin. ${ }^{19}$

Bakteriosin tersebut disintesis selama fase pertumbuhan eksponensial. Waktu inkubasi yang memanjang setelah fase stationer dapat menyebabkan aktivitas bakteriosin menurun oleh karena protease dibebaskan dari sel pada saat sel memasuki fase kematian. Bakteriosin merupakan senyawa protein yang memiliki sifat bakterisidal terhadap bakteri patogen Gram positif dan negatif dengan spektrum yang luas terhadap bakteri target yang mempunyai sifat pengikatan spesifik (specific binding site). ${ }^{20}$

Simpulan, filtrat asam laktat dan bakteriosin L. bulgaricus memberikan daya antibakteri yang berbeda pada setiap konsentrasi terhadap nilai MIC dan besar daerah hambat pertumbuhan berbagai jenis strain K. pneumoniae. Pemberian filtrat asam laktat dan bakteriosin L. bulgaricus diharapkan dapat bermanfaat bagi kesehatan karena bakteri probiotik hidup terbawa ke dalam tubuh sehingga diharapkan dapat menghambat pertumbuhan bakteri K. pneumoniae dan dapat mengatasi wabah penyakit infeksi pneumonia di masa mendatang.

\section{Ucapan Terima Kasih}

Kami mengucapkan terima kasih kepada Hibah Penelitian Muda Direktorat Jenderal Pendidikan Tinggi (DIKTI) untuk sumbangan yang diberikan. Kami juga mengucapkan terima kasih kepada Pimpinan Laboratorium Mikrobiologi Unit Penelitian Kesehatan (UPK) Fakultas Kedokteran Universitas Padjadjaran atas bantuan dalam penyediaan bahan penelitian.

\section{Daftar Pustaka}

1. Kaboosi H. Antibacterial effects of probiotics isolated from yoghurt againts some common bacterial pathogens. Afr J Microbiol Res. 2011;5(25):4363-7.

2. Fauziah PN, Nurhajati J, Chrysanti. Penghambatan adhesi berbagai strain Klebsiella pneumoniae oleh Lactobacillus bulgaricus dalam soyghurt secara in vitro pada HEp-2 cell lines dengan berbagai proses perlakuan infeksi [skripsi]. Bandung: Universitas Padjadjaran; 2012.

3. Tambekar DH, Bhutada SA. An evaluation of probiotic potential of Lactobacillus sp. from milk of domestic animals and commercial available probiotic preparations in prevention of enteric bacterial infections. Rec Res Sci Technol. 2010;2(10):82-8.

4. Johnston BC, Ma SS, Goldenberg JZ, Thorlund K, Vandvik PO, Loeb M, dkk. Probiotics for the prevention of Clostridium difficile associated diarrhea. Ann Intern Med. 2012;157(12):878-88.

5. Kartasasmita CB. Pneumonia pembunuh balita. Bul Jend Epid Bakti Husada. 2010;3:13.

6. Alsagaff H, Mukty HA. Dasar-dasar ilmu penyakit paru. Surabaya: Penerbit Airlangga 
University Press; 2005.

7. Rudan I, Boschi-Pinto C, Biloglav Z, Mulholland K, Campbell H. Epidemiology and etiology of childhood pneumonia. Bull WHO. 2008;86(5):408-16.

8. Khalili H, Soltani R, Safhami S, DashtiKhavidaki S, Alijani B. Antimicrobial resistance pattern of gram-negative bacteria of nosocomial origin at a teaching hospital in the Islamic Republic of Iran. East Mediterr Health J. 2012;18(2):172-7.

9. Seth $\mathrm{AK}$, Geringer $\mathrm{MR}$, Gurjala $\mathrm{AN}$, Abercrombie JA, Chen P, You T, dkk. Understanding the host inflammatory response to wound infection: an in vivo study of Klebsiella pneumoniae in a rabbit ear wound model. Wound Repair Regen. 2012;20(2):214-25.

10. Sanchez GV, Master RN, Clark RB, Fyyaz M, Duvvuri P, Ekta G, dkk. Klebsiella pneumoniae antimicrobial drug resistance, United States, 1998-2010. Emer Infect Dis. 2013;19(1):133-6.

11. Vidya R, Iyer PR. Antagonistic activity of probiotic organism against Vibrio cholerae and Cryptococcus neoformans. Mal J Microbiol. 2010;6(1):41-6.

12. Ogunbanwo ST, Sanni AI, Onilude AA. Characterization of bacteriocin produced by Lactobacillus plantarum F1 and Lactobacillus brevis OG1. Afr J Biotechnol. 2003;2(3):21927.

13. Vieira TI, Gondim BLC, Santiago BM, Valenca AMG. In vitro antibacterial and non-stick activity of extracts from leaves of Psidium guineense Sw. and Syzygium cumini (L.) Skeels on oral microorganisms. Rev Gaucha Ondotol Porto Alegre. 2012;60(3):359-65.
14. Maldonado NC, Silva de Ruiz C, Cecilia M, Nader-Macias ME. Inhibitory potential of Lactobacillus fermentum CRL 1058 whole cells and products. Communicating Current Research and Educational Topics and Trends in Applied Microbiology (Me'ndez-Vilas, A., ed.). The Formatex Microbiology Book Series Formatex Center. 2007;1(6):52-9.

15. Nurhajati J, Sayuti, Chrysanti, Syachroni. An in-vitro model for studying the adhesion of Lactobacillus bulgaricus in soyghurt and enteropatogenic Escherichia coli (EPEC) on HEp- 2 cells. Afr J Microbiol Res. 2012;6(24):5142-6.

16. Kumar M, Nagpal R, Verma V, Kumar A, Kaur N, Hemalatha R, dkk. Probiotic metabolites as epigenetic targets in the prevention of colon cancer. Nutr Rev. 2012;7(1):23-34.

17. Ray B, Bhunia A. Microbial stress response in the food environment. Dalam: Ray B, Bhunia A., penyunting Fundamental food microbiology Edisi ke-4. Boca Raton London New York: CRC Press; 2008. hlm. 83-6.

18. Ligocka A, Paluszak Z. Capability of lactic acid bacteria to inhibit pathogens in sewage sludge subjected to biotechnological processes. Bull Vet Inst Pulawy. 2005;49:237.

19. Usmiati S, Miskiyah, Rarah RAM. Pengaruh penggunaan bakteriosin dari Lactobacillus sp. galur SCG 1223 terhadap kualitas mikrobiologi daging sapi segar. JITV. 2009;14(2):150-66.

20. Nurhajati J, Atira, Aryantha INP, Kadek IDG. The curative action of Lactobacillus plantarum FNCC226to Saprolegnia parasitica A3 on catfish (Pangasius hypophthalamus Sauvage). IFRJ. 2012;19(4):1723-7. 